\title{
Diversity of Mercury Resistant Escherichia coli Strains Isolated from Aquatic Systems in Rio de Janeiro, Brazil
}

\author{
Raquel Costa de Luca Rebello, ${ }^{1}$ Karen Machado Gomes, ${ }^{2}$ \\ Rafael Silva Duarte, ${ }^{2}$ Caio Tavora Coelho da Costa Rachid, ${ }^{3}$ Alexandre Soares Rosado, ${ }^{3}$ \\ and Adriana Hamond Regua-Mangia ${ }^{1}$ \\ ${ }^{1}$ Departamento de Ciências Biológicas, Escola Nacional de Saúde Pública Sergio Arouca (Ensp), Fundação Oswaldo Cruz (FIOCRUZ), \\ Rua Leopoldo Bulhões 1480 Manguinhos, 21041-210 Rio de Janeiro, RJ, Brazil \\ ${ }^{2}$ Departamento de Microbiologia Médica, Instituto de Microbiologia Paulo de Góes, Universidade Federal do Rio de Janeiro (UFRJ), \\ Rio de Janeiro, RJ, Brazil \\ ${ }^{3}$ Departamento de Microbiologia Geral, Instituto de Microbiologia Paulo de Góes, Universidade Federal do Rio de Janeiro (UFRJ), \\ Rio de Janeiro, RJ, Brazil
}

Correspondence should be addressed to Adriana Hamond Regua-Mangia; regua@ensp.fiocruz.br

Received 8 March 2013; Revised 24 May 2013; Accepted 26 May 2013

Academic Editor: Steven Lee Stephenson

Copyright (c) 2013 Raquel Costa de Luca Rebello et al. This is an open access article distributed under the Creative Commons Attribution License, which permits unrestricted use, distribution, and reproduction in any medium, provided the original work is properly cited.

\begin{abstract}
Escherichia coli may harbor genetic mercury resistance markers which makes this bacterial species a promising alternative for bioremediation processes. The objective of this study was to investigate phenotypic and genetic characteristics related to diversity and mercury resistance among 178 Escherichia coli strains isolated from residential, industrial, agricultural, and hospital wastewaters and recreational waters at Rio de Janeiro city. Genetic and conventional methods were carried out in order to determine mercury resistance. Random amplification of polymorphic DNA (RAPD-PCR) and denaturing gradient gel electrophoresis (DGGE) were used to investigate genetic variability. RAPD data revealed a high degree of polymorphism among E. coli mercury resistant strains and showed reproducibility and good discriminative results. DGGE typing detected diversity within the merA gene fragment. Our findings represent an improvement in epidemiological studies of $\mathrm{Hg}^{\mathrm{R}}$ E. coli and support the evidence of nonclonal nature of mercury resistant E. coli strains circulating in rural and urban aquatic systems in Rio de Janeiro city.
\end{abstract}

\section{Introduction}

Chemical contamination of aquatic systems consists of a relevant pollution pattern causing drastic impacts on human, animal, and ecosystem health [1]. Among the various chemical contaminants, mercury plays an important role and once released in aquatic systems, mercury can resist to natural degradation processes and persist for a long time in these environments without losing its toxicity [2].

The concern about environmental contamination by this metal is due to its high toxicity, especially to the nervous system, and its bioaccumulation and biomagnification, providing persistence and wide distribution in global aquatic environment. Even regions with no mercury discharging may be affected [2-7].
Mercury toxicity to humans and other organisms is related to the chemical form to which the organisms were exposed, the route and time of exposure, dose, nutritional status, individual susceptibility, and genetic predisposition $[3,4,6,8]$. Symptoms and contamination sources are rather different in exposure to elemental mercury, inorganic or organic mercury compounds $[3,4]$. Human contamination by this metal may occur by different pathways such as vapors inhalation, contaminated food and/or water consumption, and to a lesser extent through skin contact $[3,6]$. Mercury exposure triggers a series of effects including neurological, renal, cardiovascular, respiratory, gastrintestinal, hepatic, genotoxic, immunological, dermal, reproductive, and neoplasic disorders. Exposure during pregnancy may lead to 
TABLE 1: Origin of Escherichia coli strains included in this study.

\begin{tabular}{|c|c|c|c|c|}
\hline E. coli strains & $\begin{array}{l}\text { Strains } \\
(n)\end{array}$ & $\begin{array}{l}\text { Aquatic } \\
\text { system }^{*}\end{array}$ & Sampling site & $\begin{array}{l}\text { Sampling } \\
\text { period }\end{array}$ \\
\hline $\begin{array}{l}\text { RM 1-RM } 30 \\
\text { RM 33-RM } 77\end{array}$ & 75 & RWW & $\begin{array}{l}\text { Canal do Mangue, Rio Jacaré, Canal } \\
\text { do Cunha, Rio Faria, Rio Irajá, } \\
\text { Canal do Meriti, Rio Sarapuí, Lagoa } \\
\text { Rodrigo de Freitas, Lagoa da Tijuca, } \\
\text { Lagoa de Marapendi, Rio São João }\end{array}$ & $\begin{array}{c}\text { December/2009 } \\
\text { to August } / 2010\end{array}$ \\
\hline $\begin{array}{l}\text { RM 31-RM } 32 \\
\text { RM 78-RM } 84 \\
\end{array}$ & 09 & IWW & $\begin{array}{l}\text { Rio Saracuruna, Rio Imbariê, Rio } \\
\text { Iguaçú }\end{array}$ & October/2010 \\
\hline RM 85-RM 110 & 26 & AWW & $\begin{array}{l}\text { Rio Vargem Grande, Córrego das } \\
\text { Pedras }\end{array}$ & October/2010 \\
\hline RM 111-RM 149 & 29 & HWW & Lagoa de Jacarepaguá & January/2011 \\
\hline $\begin{array}{l}\text { RM 150-RM } 154 \\
\text { RM 156-RM } 179\end{array}$ & 39 & RW & Parque Nacional da Praia de Ramos & January/2011 \\
\hline
\end{tabular}

${ }^{*}$ RWW: residential wastewater; IW: industrial wastewater; AWW: agricultural wastewater; HWW: hospital wastewater, and RW: recreational waters.

malformations, mental retard, cerebral palsy, seizures, and death $[3,4,6,8]$.

Mercury resistance is one of the most studied toxic metals resistance mechanisms [7]. It has been reported that some bacteria and fungi isolated from different sources have developed resistance mechanisms that enable them to survive even in environments highly contaminated by mercury [9]. There are several described bacterial mechanisms that confer protection to harmful concentrations of mercury [10]. Among them, we highlight the mercury enzymatic detoxification, promoted by the mercuric reductase protein (MerA), which catalyze the reduction of $\operatorname{Hg}(\mathrm{II})$ to volatile $\operatorname{Hg}(0)$ [11, 12]. Considering the genetic of MerA expression, the $\mathrm{Hg}$ resistance (mer) operon presents a fundamental role in regulation, $\mathrm{Hg}$ binding, and organomercury degradation. It consists of essential genes as merR (responsible for the regulation of the operon), merT/merP (transport of mercury into the bacterial cell), merA (reduction of ionic mercury), and accessory genes such as merB, merC, merD, merE, merF, and merG, that encode proteins that add other skills to microorganisms [13, 14]. MerR protein can act both as a repressor and activator of transcription. In the absence of $\mathrm{Hg}^{2+}, \mathrm{MerR}$ acts as repressor by binding to the mer operon operator region and preventing the transcription of merTPCAD. In presence of $\mathrm{Hg}^{2+}$, it binds to one of two MerR binding sites forming a complex that acts as an activator of mer operon transcription [15]. Mermediated approaches have had broad applications in the bioremediation of mercury-contaminated environments and industrial waste streams $[8,11,12,16,17]$.

Mercury resistance in bacteria has been observed in both Gram-positive (S. aureus, Bacillus sp.) and Gram-negative bacteria (E. coli, P. aeruginosa, Serratia marcescens, and Thiobacillus ferrooxidans) $[12,16]$. Mercury resistance is encoded on genetic elements such as plasmids and transposons, which contributes to horizontal dissemination among different bacteria and widespread occurrence in different bacterial groups and environments [12].

In Gram-negative bacteria, including E. coli, the mer operon has already been described [18]. However, epidemiological and genetic studies related to mercury resistance are scarce. Therefore, the investigation of the mercury resistance features has been crucial to improve bioremediation processes in contaminated environments in order to minimize human exposure and consequent adverse health effects.

In the present study, E. coli isolates from aquatic systems, in the city of Rio de Janeiro, Brazil, were characterized by phenotypic and genotypic traits related to mercury resistance. Bacteriological tests were carried out in order to determine mercury susceptibility, and molecular approaches based on amplification assays were used to investigate the presence and diversity of mercury resistance gene (merA).

\section{Materials and Methods}

2.1. Water Sampling. Samples were selected and grouped according to potential contamination sources in the city of Rio de Janeiro, Brazil. We studied five aquatic environments: residential, industrial, agricultural, and hospital wastewaters and recreational waters (Table 1 ).

2.2. Sample Collection. Collection procedure consisted of membrane filtration method with some modifications [19]. An aliquot of $60 \mathrm{~mL}$ of water was aspirated from the upper layer of the water column to a depth of approximately 30 centimeters with a syringe holder adapted to sterile filtration. The aspirate was filtered on a $0.22 \mu \mathrm{m}$ cellulose acetate membrane (Millipore) and transported under refrigeration for immediate laboratory processing.

2.3. Escherichia coli Isolation and Identification. The membrane containing the retained cells was incubated in $20 \mathrm{~mL}$ of tryptic soy broth (TSB, Difco) for $18-24 \mathrm{hr}$ at $37^{\circ} \mathrm{C}$. After a period of bacterial growth, an aliquot of the broth, diluted $(1: 10,1: 50$, and $1: 100)$ in saline $0.9 \% \mathrm{NaCl}(\mathrm{w} / \mathrm{v})$, was streaked on eosin methylene blue agar (EMB, Difco). After $18-24 \mathrm{~h}$ of incubation at $37^{\circ} \mathrm{C} 10-15$ bacterial colonies, lactose positive and lactose negative, were selected based on morphological and physiological characteristics suggestive of E. coli. For confirmation of genus and species, the selected colonies were inoculated in culture medium for biochemical 
identification (Probac of Brazil). E. coli biochemical pattern includes gas production from glucose $(+)$, glucose utilization $(+)$, hydrogen sulfide production $(-)$, urea hydrolysis $(-)$ and tryptophan deamination (-), motility (variable), indole production $(+)$, decarboxylation of lysine (variable), and citrate (-) [20]. Bacterial cells identified as E. coli were stored at $-20^{\circ} \mathrm{C}$ in TSB plus $15 \%$ glycerol (v/v) until analysis. This study included a total of 178 E. coli isolates (RM 1 to RM 179) (Table 1).

2.4. Mercury Resistance Phenotype. In order to classify E. coli as resistant or sensitive to mercury, each strain was tested on nutrient agar (NA, Difco) supplemented with $5 \mu \mathrm{M}$ of $\mathrm{Hg}^{2+}$. Evidence of bacterial growth after a period of $24-48 \mathrm{~h}$ at $37^{\circ} \mathrm{C}$ allowed to classify E. coli strains as $\mathrm{Hg}$ resistant $\left(\mathrm{Hg}^{\mathrm{R}}\right)$. E. coli ATCC 35218 (Hg resistant) and E. coli ATCC 23724 (Hg susceptible) were used as control strains. When no growth was observed, a strain was considered as sensitive. These tests were done in duplicate.

2.5. Minimal Inhibitory Concentration (MIC). MIC determination was performed following the methodology described by Andrews [21] with some modifications. Overnight cultures of the isolates in nutrient broth ( $\mathrm{NB}$, Difco) containing $1 \mu \mathrm{M} \mathrm{Hg}$ were adjusted in saline $\mathrm{NaCl} 0.9 \%(\mathrm{w} / \mathrm{v})$ in order to contain $1.5 \times 10^{9}$ bacterial cells/mL (McFarland 0.5 ). An aliquot of $50 \mu \mathrm{L}$ was inoculated in nutrient agar plates containing 10 to $40 \mu \mathrm{M} \mathrm{Hg}$. After $24-48 \mathrm{~h}$ at $37^{\circ} \mathrm{C}$, the MIC value was determined by observing bacterial growth on agar plates in the presence of the lowest $\mathrm{Hg}$ concentration. MIC tests were performed with those $E$. coli strains exhibiting mercury resistance phenotype $\geq 5 \mu \mathrm{M} \mathrm{Hg}$. All experiments were performed in duplicate.

2.6. merA Detection. All strains were screened for the presence of merA sequence by PCR amplifications as described by Ní Chadhain and colleagues [22], with some modifications. Each reaction was carried out in $25 \mu \mathrm{L}$ PCR mixture containing $3 \mu \mathrm{L}$ of bacterial DNA obtained through thermal extraction of $18-24 \mathrm{~h}$ bacterial growth in tryptic soy broth (TSB, Difco), $2.5 \mu \mathrm{L}$ of $10 \mathrm{X}$ buffer (Invitrogen), $2 \mathrm{mM} \mathrm{MgCl}_{2}$ (Invitrogen), $0.2 \mathrm{mM}$ dNTP (Invitrogen), $30 \mu \mathrm{M}$ of each primer, and $1 \mathrm{U}$ of Platinum Taq DNA polymerase (Invitrogen). The pair of primers used was Als-n.F $\left(5^{\prime}\right.$-TCCGCAAGTNGCVACBGTNGG-3 $\left.{ }^{\prime}\right)$ and A5-n.R ( $5^{\prime}$ ACCATCGTCAGRTARGGRAAVA-3 $\left.{ }^{\prime}\right)$. PCR reaction was conducted in Mastercycler Personal thermocycler (Eppendorf) under the following amplification conditions: initial denaturing step at $94^{\circ} \mathrm{C}$ for $5 \mathrm{~min}$, followed by 45 cycles at $94^{\circ} \mathrm{C}$ for $10 \mathrm{sec}, 68^{\circ} \mathrm{C}$ for $40 \mathrm{sec}$, and $72^{\circ} \mathrm{C}$ for $1 \mathrm{~min}$ with a final extension at $72^{\circ} \mathrm{C}$ for $7 \mathrm{~min}$. Approximately $10 \mu \mathrm{L}$ of the resulting amplification products was added to $2 \mu \mathrm{L}$ of running buffer (gel loading buffer, Invitrogen) and separated by electrophoresis on agarose gel at $1.3 \%$ concentration $(\mathrm{w} / \mathrm{v})$ prepared in Tris-Borate-EDTA $0.5 \mathrm{X}(5 \mathrm{X}-0.89 \mathrm{M}$ Tris- $\mathrm{HCl}$ (LGC Biotech) 0.89 M boric acid (Merck) and 0.024 M EDTA (LGC Biotech) ( $\mathrm{pH} 8.4)$ ) at a constant voltage of $70 \mathrm{~V}$. Electrophoresis gel was stained with $0.5 \mu \mathrm{g} / \mathrm{mL}$ ethidium bromide solution (Invitrogen) over a period of $15 \mathrm{~min}$ and washed in distilled water for about $30 \mathrm{~min}$. Gel was visually inspected by using an ultraviolet light transilluminator (UVITec, Cambridge, UK) and photographed in digital image capture system (silver UVIPro, Cambridge, UK). To estimate the size of the fragments a $100 \mathrm{bp}$ DNA ladder standard (Invitrogen) was used. E. coli strains ATCC 35218 (Hg resistant) and ATCC 23724 (Hg sensitive) were used as controls.

2.7. Random Amplification of Polymorphic DNA (RAPD$P C R)$. RAPD-PCR analysis was performed according to the methodology described by Pacheco and colleagues [23]. Each reaction was carried out in a $30 \mu \mathrm{L}$ PCR mixture containing $2 \mu \mathrm{L}$ of bacterial DNA, $3 \mu \mathrm{L}$ of $10 \mathrm{X}$ buffer (Invitrogen), $250 \mu \mathrm{M}$ each dNTP (Invitrogen), $3 \mathrm{mM} \mathrm{MgCl}_{2}$ (Invitrogen), $1 \mathrm{U}$ of Taq DNA polymerase (Invitrogen), and $30 \mu \mathrm{M}$ of each primer. Primers used were $1247\left(5^{\prime}\right.$-AAGAGCCCGT$\left.3^{\prime}\right), 1254\left(5^{\prime}\right.$-CCGCAGCCAA- $\left.3^{\prime}\right), 1290$ (5'-GTGGATGCGA$\left.3^{\prime}\right)$, and A04 (5'-AATCGGGCTG- $\left.3^{\prime}\right)$. The reaction was conducted in a Mastercycler Personal thermocycler (Eppendorf) under the following amplification conditions: an initial denaturing step at $94^{\circ} \mathrm{C}$ for $1 \mathrm{~min}$, followed by 4 cycles at $94^{\circ} \mathrm{C}$ for $4 \mathrm{~min}, 37^{\circ} \mathrm{C}$ for $4 \mathrm{~min}$, and $72^{\circ} \mathrm{C}$ for $4 \mathrm{~min}$, 30 cycles at $94^{\circ} \mathrm{C}$ for $1 \mathrm{~min}, 37^{\circ} \mathrm{C}$ for $1 \mathrm{~min}$, and $72^{\circ} \mathrm{C}$ for $2 \mathrm{~min}$ with a final extension at $72^{\circ} \mathrm{C}$ for $10 \mathrm{~min}$. Reaction products were analyzed by electrophoresis in $1.5 \%$ agarose gels and stained with ethidium bromide. RAPD profiles were inspected visually and defined according to the presence or absence and intensity of polymorphic bands. A $1 \mathrm{~kb}$ DNA ladder was used as a molecular weight marker (GIBCO, BRL, Gaithersburg, MD, USA). Semiautomated analysis used the UVI Soft Image Acquisition and Analysis Software, program UVIPro bandmap version 11.9 (UVItec, Cambridge, UK). Cluster analysis was done by using the unweighted pair group method with arithmetic averages (UPGMA) of the Image Analysis System. The percentages of similarity were estimated by the Dice coefficient. The reproducibility of the RAPD amplifications was assessed using the selected primers with different DNA samples isolated independently from the same strain and amplified at different times.

2.8. Denaturing Gradient Gel Electrophoresis (DGGE). DGGE analysis was performed according to the methodology described by Muyzer and colleagues with some modifications [24]. AxyPrep DNA Gel Extraction kit(Axygen Biosciences) was used for purificating the PCR-merA DNA fragment (285 bp). For PCR-DGGE reaction a final volume of $25 \mu \mathrm{L}$ in amplification reactions containing $3 \mu \mathrm{L}$ of purified DNA, $2.5 \mu \mathrm{L} 10 \mathrm{X}$ buffer (Invitrogen), $2 \mathrm{mM} \mathrm{MgCl}_{2}$ (Invitrogen), $0.2 \mathrm{mM}$ dNTPs (Invitrogen), $30 \mu \mathrm{M}$ of each primer, $1 \%$ formamide, and $1 \mathrm{U}$ of Platinum Taq DNA polymerase (Invitrogen) was used. The pair of primers for amplification was Alsn.F (5' ${ }^{\prime}$-TCCGCAAGTNGCVACBGTNGG-3') and A5-n.R $\left(5^{\prime}\right.$-ACCATCGTCAGRTARGGRAAVA- $\left.3^{\prime}\right)$. The reaction was conducted in Mastercycler Personal thermocycler (Eppendorf) and programmed for an initial denaturation of $94^{\circ} \mathrm{C}$ for $5 \mathrm{~min}$ followed by 45 cycles of $94^{\circ} \mathrm{C}$ for $10 \mathrm{sec}, 68^{\circ} \mathrm{C}$ for $40 \mathrm{sec}$, and $72^{\circ} \mathrm{C}$ for $1 \mathrm{~min}$, with a final extension of $72^{\circ} \mathrm{C}$ for $7 \mathrm{~min}$. Approximately $25 \mu \mathrm{L}$ of amplified PCR product was added to $15 \mu \mathrm{L}$ of DNA electrophoresis dye $(0.005 \mathrm{~g}$ 

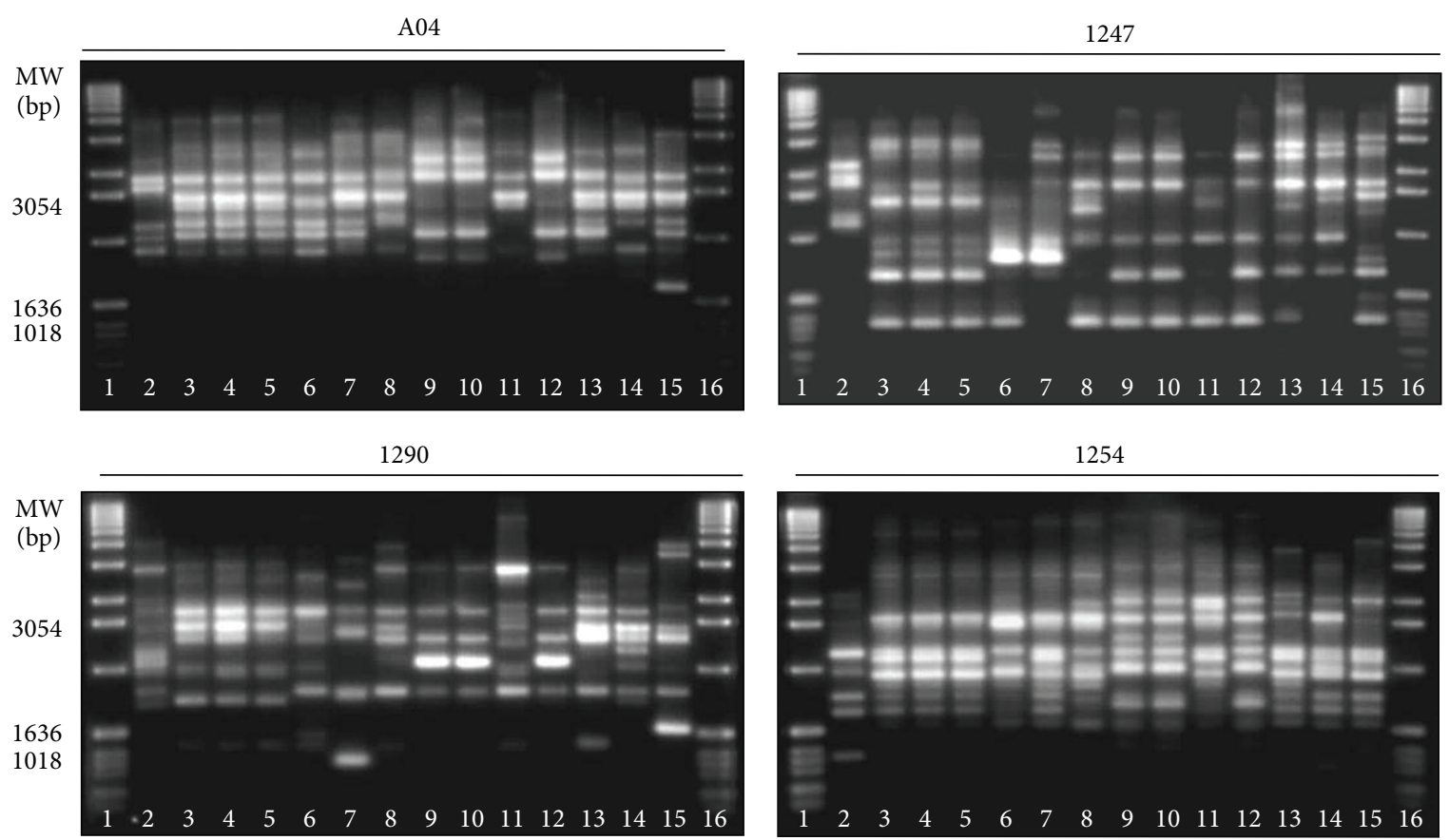

FIGURE 1: RAPD-PCR profiles of representative E. coli merA+ strains obtained by using 4 different primers (A04, 1247, 1290, and 1254). Lanes 1, 16: 1 Kb DNA ladder; Lane 2: strain RM 1; Lane 3: strain RM 7; Lane 4: strain RM 8; Lane 5: strain RM 9; Lane 6: strain RM 17; Lane 7: strain RM 20; Lane 8: strain RM 31; Lane 9: strain RM 37; Lane 10: strain RM 44; Lane 11: strain RM 45; Lane 12: strain RM 46; Lane 13: strain RM 61; Lane 14: strain RM 150; Lane 15: strain RM 165.

Bromophenol blue, 0.005 g xylene cyanol, 7 mL glycerol P.A., and $3 \mathrm{~mL}$ deionized water) and ran on a polyacrylamide gel $(8 \% \mathrm{w} / \mathrm{v}$ of acrylamide/bisacrylamide ratio $37.5: 1)$ with a linear denaturant gradient ranging from $55 \%$ to $80 \%$ (where $100 \%$ is a solution of $7 \mathrm{M}$ urea and $40 \%$ formamide $\mathrm{v} / \mathrm{v}$ ). Electrophoresis was performed in equipment using the Dcode Universal Mutation System (BIO-Rad) and conducted at constant voltage of $100 \mathrm{~V}$ at $60^{\circ} \mathrm{C}$ for $6 \mathrm{~h}$ in $0.5 \mathrm{X}$ Tris-acetate (10 mM Tris-acetate, $5 \mathrm{mM}$ Sodium Acetate, $25 \mathrm{mM}$ EDTA, and $\mathrm{pH}$ 7.4). After electrophoresis the gel was stained with Sybr Green (Molecular Probes, OR, USA) for 30 minutes and visualized under UV transilluminator. The reproducibility of the assay was tested by loading three PCR products for each sample on DGGE gels.

\section{Results}

3.1. Mercury Resistance Phenotype and Minimal Inhibitory Concentration (MIC). A total of 164 strains were classified as mercury resistant $\left(\mathrm{Hg}^{\mathrm{R}}\right)$ and represented $92.1 \%$ of the $E$.

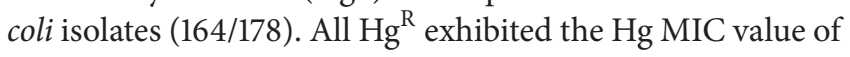
$10 \mu \mathrm{M}$.

3.2. PCR Amplification of merA Gene. Among E. coli strains analyzed in this study, 14 harbored the $285 \mathrm{bp}$ merA gene fragment described by Ní Chadhain and colleagues [22]. E. coli strains carrying the 285 bp merA gene corresponded to $14.7 \%(11 / 75)$ of the isolates obtained from residential wastewaters samples, $11.1 \%$ (1/9) from industrial wastewaters samples, and $6.9 \%(2 / 29)$ from hospital wastewaters samples.
3.3. Random Amplification of Polymorphic DNA (RAPD$P C R)$. The diversity within the $E$. coli merA+ strains was investigated by RAPD-PCR using the primers A04, 1247, 1290, and 1254 (Figure 1). RAPD typing revealed a high degree of diversity among E. coli strains. Reactions performed with primers A04, 1247, 1290 (60\% GC, each), and 1254 (70\% GC) resulted in $11,10,10$, and 10 different RAPD profiles, respectively. The total number of polymorphic bands was 5-9 bands (A04), 4-11 bands (1247), 5-10 bands (1290), and 8-12 bands (1254) ranging from 600-4100 bp, 200-5600 bp, 450$8000 \mathrm{bp}$, and $250-9000 \mathrm{bp}$, respectively. There was no direct correlation between higher $\mathrm{G}+\mathrm{C}$ content and the ability of the primer to detect polymorphism. The different primers used to investigate the overall chromosomal relatedness among $E$. coli strains were strongly correlated. The cluster analysis revealed a bacterial population arranged into separate branches or small clonal groups, exhibiting Dice similarity index ranging from $6-100 \%, 18-100 \%, 6-100 \%$, and $6-100 \%$ for primers $1290,1254,1247$, and A04 (Figure 2), respectively. Close relatedness was specially observed among merA+E. coli strains isolated from the same aquatic system (Table 2, Figure 2). Identical RAPD profiles were observed among residential wastewaters isolates: RM 7, RM 8, and RM 9, isolated from Canal do Cunha, and RM 37, RM 44, and RM 46 from Lagoa Rodrigo de Freitas.

3.4. Denaturing Gradient Gel Electrophoresis (DGGE). Electrophoresis technique on denaturing gradient gel enabled the detection of variability within the $285 \mathrm{bp}$ gene fragment associated with mercury resistance (merA). Supporting the results obtained from RAPD-PCR, RM 7, RM 8, and RM 


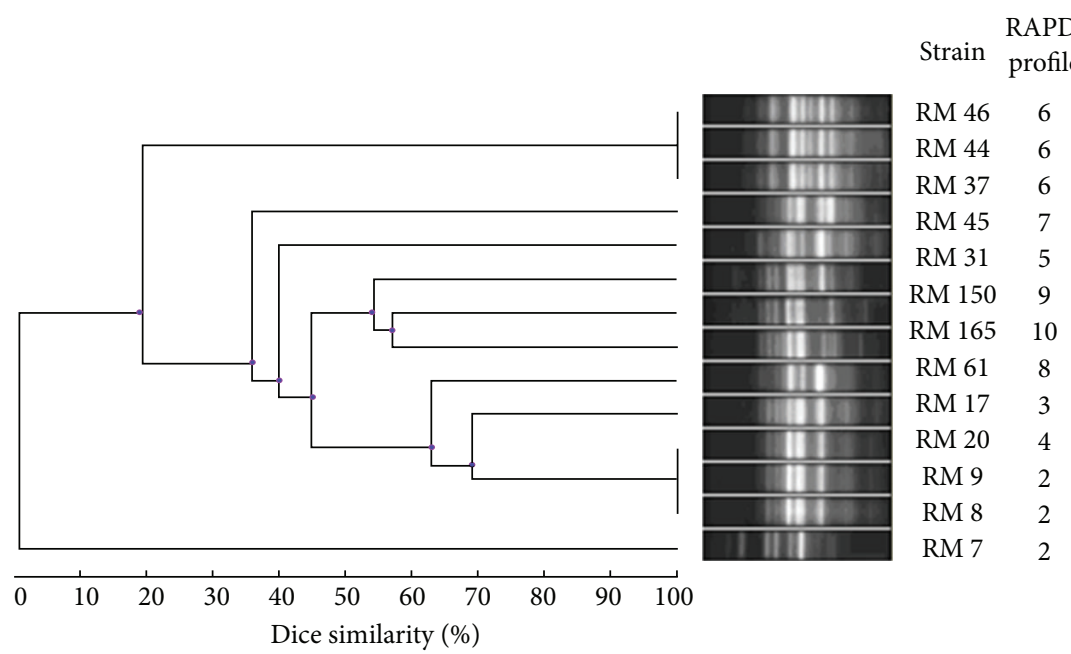

Figure 2: Dendrogram generated by the Dice coefficient and clustering by unweighted pair group method with arithmetic mean and respective RAPD profiles of merA+ Escherichia coli isolates using 1254 primer.

TABLE 2: Genetic and phenotypic traits of E. coli strains carrying the $285 \mathrm{bp}$ merA fragment according to aquatic systems and sampling sites.

\begin{tabular}{|c|c|c|c|c|c|c|c|}
\hline \multirow{2}{*}{ E. coli strain } & \multirow{2}{*}{ Aquatic system ${ }^{*}$} & \multirow{2}{*}{ Sampling site } & \multirow{2}{*}{ MIC } & \multicolumn{4}{|c|}{ RAPD profile } \\
\hline & & & & $\mathrm{A} 04$ & 1247 & 1290 & 1254 \\
\hline RM 1 & \multirow{6}{*}{ RWW } & Canal do Mangue & $10 \mu \mathrm{M}$ & 1 & 1 & 1 & 1 \\
\hline RM 7 & & Canal do Cunha & $10 \mu \mathrm{M}$ & 2 & 2 & 2 & 2 \\
\hline RM 8 & & Canal do Cunha & $10 \mu \mathrm{M}$ & 2 & 2 & 2 & 2 \\
\hline RM 9 & & Canal do Cunha & $10 \mu \mathrm{M}$ & 2 & 2 & 2 & 2 \\
\hline RM 17 & & Rio Irajá & $10 \mu \mathrm{M}$ & 3 & 3 & 3 & 3 \\
\hline RM 20 & & Rio Irajá & $10 \mu \mathrm{M}$ & 4 & 4 & 4 & 4 \\
\hline RM 31 & IWW & Rio Iguaçú & $10 \mu \mathrm{M}$ & 5 & 5 & 5 & 5 \\
\hline RM 37 & \multirow{5}{*}{ RWW } & Lagoa Rodrigo de Freitas & $10 \mu \mathrm{M}$ & 6 & 6 & 6 & 6 \\
\hline RM 44 & & Lagoa Rodrigo de Freitas & $10 \mu \mathrm{M}$ & 6 & 6 & 6 & 6 \\
\hline RM 45 & & Lagoa Rodrigo de Freitas & $10 \mu \mathrm{M}$ & 7 & 7 & 7 & 7 \\
\hline $\mathrm{RM} 46$ & & Lagoa Rodrigo de Freitas & $10 \mu \mathrm{M}$ & 8 & 6 & 6 & 6 \\
\hline RM 61 & & Lagoa de Marapendi & $10 \mu \mathrm{M}$ & 9 & 8 & 8 & 8 \\
\hline RM 150 & \multirow{2}{*}{ HWW } & Lagoa de Jacarepaguá & $10 \mu \mathrm{M}$ & 10 & 9 & 9 & 9 \\
\hline RM 165 & & Lagoa de Jacarepaguá & $10 \mu \mathrm{M}$ & 11 & 10 & 10 & 10 \\
\hline
\end{tabular}

${ }^{*}$ RWW: residential wastewater; IW: industrial wastewater; HWW: hospital wastewater.

9 isolates also showed identical DGGE pattern (Figure 3). Despite the diversity observed, no significant differences among the DGGE band patterns were observed.

\section{Discussion}

4.1. Mercury Resistance Phenotype and Minimal Inhibitory Concentration (MIC). Many studies have been conducted in order to determine the mercury resistance in environmental bacteria by testing the minimum inhibitory concentration [25-28]. There is not a standard protocol for determining the MIC of heavy metals. Liquid and/or solid media with different chemical compositions have been commonly used for these assays, as well as variation of metals concentrations. Methodology itself may offer some obstacles such as precipitation and volatilization of the solution and complexes between the metal and culture medium components. These variations, if not minimized before its application, may directly influence the result obtained [26]. So, it is very difficult to compare the obtained results with previous studies because of the great diversity of MIC values and the procedures adopted, especially considering the broad spectrum of mercury resistant bacteria that require specific conditions for growing and laboratory processing.

The ubiquity of bacterial mercury resistance has been observed in environments worldwide and is supposed to be the result of external interference by humans and other animals through environmental contamination for several years $[5,12,26]$. There were no reports about mercury contamination in the sampling sites; however, $\mathrm{Hg}$ resistance was widely detected. Bacterial resistance to mercury present in the environment is considered as one of many examples of 


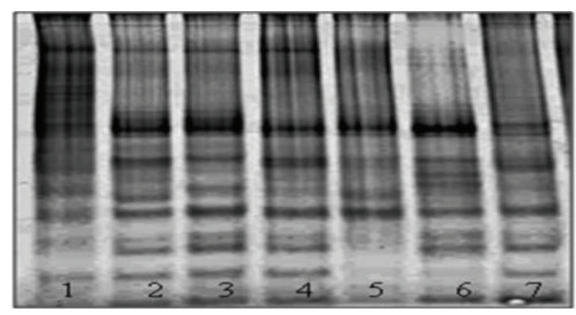

FIGURE 3: DGGE profiles of PCR-amplified merA+ gene fragment from E. coli strains. Lane 1: strain RM 1; Lane 2: strain RM 7; Lane 3: strain RM 8; Lane 4: strain RM 9; Lane 5: strain RM 17; Lane 6: strain RM 20; Lane 7: strain RM 31.

genetic and physiological adaptation of microbial communities exposed to contaminants. Several factors have been found to contribute to this phenotype in the rural and urban areas including the use of mercury-based fungicide in the paper industry, agriculture, and hospital disinfectants. These factors may encourage selective activities and result in mercury resistance in open environment [29]. Additionally, toxic metal resistance genes are commonly found in environmental bacteria, and these genes may confer coresistance or crossresistance to antimicrobial drugs codified on the same genetic element $[26,30]$. So, selection of microbial communities exposed to toxic levels of the metal or submitted to the coselection mechanisms has led to high rates of circulation of these resistant bacteria in aquatic systems [31,32].

4.2. PCR Amplification of merA Gene. The genetic system evolved as mer operon is the only well-known bacterial mercury resistance system with high yield transformation of its toxic target into volatile nontoxic forms [27, 31, 33$35]$, particularly in Gram-negative bacteria [14, 22]. The mer locus is found to be widely distributed among bacterial lineages, and mer-like sequences have been described. Several biochemical mechanisms are identified, and the complexity among the ecological niche of mercury-resistant microbes is still not fully described $[10,35]$. merA plays a key role on mercury resistance of bacterial community exposed to mercury contamination, but the combinatorial action of genetic determinants seems to confer a broad spectrum mercury detoxification system [10, 35]. So, the involvement of additional genetic determinants not investigated here, acting as effectors or regulators genes, must be considered for the expression of mercury resistance phenotype among merA negative E. coli strains. merA gene was detected in E. coli isolated from residential wastewaters (11/75), industrial wastewaters (1/9), and hospital wastewaters $(2 / 29)$. The higher frequency of merA+E. coli strains obtained from residential wastewaters compared to industrial and hospital wastewaters may be related to several factors such as the representative sampling of each area investigated and involvement of additional genetic determinants as well as related to the intrinsic characteristics of the rural and urban locations.

4.3. Random Amplification of Polymorphic DNA (RAPD$P C R)$. RAPD-PCR is a recognized powerful tool showing high discriminatory potential, reproducibility, sensibility, and specificity under well-standardized protocols. Random amplification of polymorphic DNA (RAPD) has been successfully used as a molecular typing system for studies on diversity of E. coli population [23,36].

RAPD typing revealed levels of polymorphism that are consistent with previously reported observations for E. coli and has been attributed to the high plasticity of this bacterial species. Several molecular approaches mainly based on genetic techniques have been successfully applied in order to assess the clonal nature and variability within species [23, 36]. The occurrence of distinct patterns of E. coli phylogenetic distribution provides evidence of both vertical and horizontal transmission [37-39]. The mechanisms of genetic diversification contribute to $E$. coli evolution and creation of new variants, as this bacterial species is often subjected to DNA rearrangements, excisions, transfers, and acquisitions $[37,40]$. There are several highly adapted clones that have acquired specific virulence elements which confer an increased ability to adapt to new niches. Such plasticity may confer ability to acclimate environmental bacteria to new niches allowing these microorganisms to become members of microbial communities in a variety of environments, even facing conditions very different from their primary habitat $[36,38,39,41]$. RAPD-PCR approach was used to investigate the overall chromosomal relatedness among merA+ strains and revealed a high genetic diversity population suggesting that mercury resistance is widely dispersed in E. coli. The observed genotypic diversity led us to suppose that, in Rio de Janeiro, merA+E. coli isolates consist of nonrelated epidemiological strains and may represent distinct evolutionary lineages. Despite the genetic variability, clustering analysis revealed that the degree of diversity was to a lesser extent among E. coli strains obtained from the same aquatic environment evidencing the circulation of closely related strains.

\subsection{Denaturing Gradient Gel Electrophoresis (DGGE).} DGGE fingerprinting is a technique widely used in microbial ecology studies and has been focused on studies of genetic diversity and bacterial communities from several environments [17, 42]. Variability within merA gene has been described, and diverse MerA protein homologs have been identified in both archaeal as well as bacterial genomes but not in eukaryal genomes [17]. The increased complexity of mer operons can be attributed to the gradual addition of functions involved in the regulation of the operon by $\mathrm{Hg}, \mathrm{Hg}$ transport, and organomercury resistance [17]. The diversity of merA gene in Gram-negative and Gram-positive bacteria has been accessed by several approaches including those using restriction fragment assays [27, 31, 33, 34]. In all these studies, a high genetic variability was detected in merA determinant carried by bacterial species from different environments. However, RFLP technique is limited since it relies on specific target, requiring prior knowledge of the sequences to be analyzed. In the present study, DGGE was used to investigate the merA+ variability among E. coli mercury resistant.

DGGE typing revealed diversity within the $285 \mathrm{bp}$ merA fragment corroborating previous findings that described 
the occurrence of genetic exchanges in mercury resistance gene as a result of addition, rearrangements, excisions, and horizontal transfer.

Ní Chadhain and colleagues [22] developed a protocol using degenerated primers and detected high diversity within mer $A$ sequence from evolutionary distinct Gram-bacteria. In our study, this methodology allowed the detection of variability in the $285 \mathrm{bp}$ merA fragment among $14 \mathrm{E}$. coli strains (Figure 3). These results are in agreement with previous findings regarding the widespread occurrence and diversity of mercury resistance markers among distinct microbial populations from several environments, including soils and sediments, aquatic systems, animals, and clinical isolates [13, $14,27,28,31,32]$. The high plasticity found in the bacterial genome contributes to the diversity and dissemination of genetic markers favoring its circulation in geographically dispersed environments, even between distinct evolutionary lineages.

E. coli isolates sharing similar RAPD profiles were found to exhibit the same merA DGGE pattern suggesting the circulation of conserved or partially conserved merA sequence among closely related strains. The molecular approaches used as fingerprint tools were found to be accurate and useful methods in distinguishing between closely related bacteria. The obtained results are relevant to our understanding on the characteristics of mercury resistant $E$. coli circulating in natural environments in aquatic systems in Rio de Janeiro. Our findings substantially expand our knowledge about mer evolution and biodiversity of these microorganisms, and contribute to studies on bioremediation process and environmental management of $\mathrm{Hg}$ contamination.

\section{Conclusions}

The present study detected a wide dissemination of E. coli isolates resistant to mercury in distinct aquatic systems in the city of Rio de Janeiro possibly due to selective activities with varying patterns of exposure to $\mathrm{Hg}$. Genetic analysis of merA+ strains revealed high degree of diversity among the bacterial population indicating that mercury resistance is widely dispersed in E. coli. These findings suggest that, in the city of Rio de Janeiro, merA+E. coli may constitute bacterial communities epidemiologically independent and may represent distinct evolutionary lineages. The variability detected within the $285 \mathrm{bp}$ merA fragment possibly reflects the occurrence of specific genetic events. E. coli strains sharing RAPD profile and DGGE band pattern reinforce the hypotheses of circulation of conserved merA sequence among closely related strains. In the light of the pathogenicity attributed to E. coli population, more accurate analyses are required for applications in bioremediation processes.

\section{Conflict of Interests}

The authors have declared that no conflict of interests exists.

\section{Acknowledgments}

This work was supported by a Grant from Fundação Carlos Chagas Filho de Amparo à Pesquisa do Estado do
Rio de Janeiro (E-26/110.787/2010) and Coordenação de Aperfeiçoamento de Pessoal de Nível Superior (CAPES). The authors would like to thank Adriana de Lima Bezerra, Marcelo Sampaio, and Thiago Figueiredo for technical assistance in the collection of water samples. The authors also thank the laboratory at Departamento de Saneamento e Saúde Ambiental for conducting the mercury resistance phenotypic assays.

\section{References}

[1] A. Bafana, "Mercury resistance in Sporosarcina sp. G3," BioMetals, vol. 24, no. 2, pp. 301-309, 2011.

[2] F. A. Azevedo, Toxicologia do Mercúrio, Editora Rima, São Paulo, Brazil, 2003.

[3] United Nations Environmental Programme, "Global mercury assessment," 2002, http://www.chem.unep.ch/mercury/report/ gma-report-toc.htm.

[4] A. L. Oliveira Da Silva, P. R. G. Barrocas, S. Do Couto Jacob, and J. C. Moreira, "Dietary intake and health effects of selected toxic elements," Brazilian Journal of Plant Physiology, vol. 17, no. 1, pp. 79-93, 2005.

[5] V. M. Câmara, A. P. Silva, and J. A. Cancio, "Notas para 17 a constituição de um programa de vigilância ambiental dos riscos e efeitos da exposicão do mercúrio metálico em áreas de produção de ouro," Informe Epidemiológico Do SUS, vol. 2, pp. 35-44, 1998.

[6] A. T. Jan, I. Murtaza, A. Ali, and Q. M. R. Haq, "Mercury pollution: an emerging problem and potential bacterial remediation strategies," World Journal of Microbiology and Biotechnology, vol. 25, no. 9, pp. 1529-1537, 2009.

[7] F. M. M. Morel, A. M. L. Kraepiel, and M. Amyot, "The chemical cycle and bioaccumulation of mercury," Annual Review of Ecology and Systematics, vol. 29, pp. 543-566, 1998.

[8] P. B. Tchounwou, W. K. Ayensu, N. Ninashvili, and D. Sutton, "Environmental exposure to mercury and its toxicopathologic implications for public health," Environmental Toxicology, vol. 18, no. 3, pp. 149-175, 2003.

[9] M. M. Ball, P. Carrero, D. Castro, and L. A. Yarzábal, "Mercury resistance in bacterial strains isolated from tailing ponds in a gold mining area near El Callao (Bolívar State, Venezuela)," Current Microbiology, vol. 54, no. 2, pp. 149-154, 2007.

[10] D. W. Boening, "Ecological effects, transport, and fate of mercury: a general review," Chemosphere, vol. 40, no. 12, pp. 1335-1351, 2000.

[11] T. Barkay, S. M. Miller, and A. O. Summers, "Bacterial mercury resistance from atoms to ecosystems," FEMS Microbiology Reviews, vol. 27, no. 2-3, pp. 355-384, 2003.

[12] A. M. Osborn, K. D. Bruce, P. Strike, and D. A. Ritchie, "Distribution, diversity and evolution of the bacterial mercury resistance (mer) operon," FEMS Microbiology Reviews, vol. 19, no. 4, pp. 239-262, 1997.

[13] L. F. Caslake, S. S. Harris, C. Williams, and N. M. Waters, "Mercury-resistant bacteria associated with macrophytes from a polluted lake," Water, Air, and Soil Pollution, vol. 174, no. 1-4, pp. 93-105, 2006.

[14] C. A. Liebert, J. Wireman, T. Smith, and A. O. Summers, "Phylogeny of mercury resistance (mer) operons of gramnegative bacteria isolated from the fecal flora of primates," Applied and Environmental Microbiology, vol. 63, no. 3, pp. 1066-1076, 1997. 
[15] M. T. Madigan, J. M. Martinko, P. V. Dunlap, and D. P. Clark, Microbiologia de Brock, Artmed, Porto Alegre, Brazil, 2010.

[16] T. K. Misra, "Bacterial resistances to inorganic mercury salts and organomercurials," Plasmid, vol. 27, no. 1, pp. 4-16, 1992.

[17] E. S. Boyd and T. Barkay, "The mercury resistance operon: from an origin in a geothermal environment to an efficient detoxification machine," Frontiers in Microbiology, vol. 3, pp. 113, 2012.

[18] M. Zeyaullah, G. Nabi, R. Malla, and A. Ali, "Molecular studies of $E$. coli mercuric reductase gene (merA) and its impact on human health," Nepal Medical College Journal, vol. 9, no. 3, pp. 182-185, 2007.

[19] N. Ramaiah and J. De, "Unusual rise in mercury-resistant bacteria in coastal environs," Microbial Ecology, vol. 45, no. 4, pp. 444-454, 2003.

[20] E. W. Koneman, S. D. Allen, V. R. Dowell, and H. M. Sommers, Diagnóstico Microbiológico: Texto e Atlas Colorido, Medicina Panamericana Editora do Brasil ltda., São Paulo, Brazil, 2008.

[21] J. M. Andrews, "Determination of minimum inhibitory concentrations," Journal of Antimicrobial Chemotherapy, vol. 48, pp. S5-S16, 2001.

[22] S. M. Ní Chadhain, J. K. Schaefer, S. Crane, G. J. Zylstra, and T. Barkay, "Analysis of mercuric reductase (merA) gene diversity in an anaerobic mercury-contaminated sediment enrichment," Environmental Microbiology, vol. 8, no. 10, pp. 1746-1752, 2006.

[23] A. B. F. Pacheco, B. E. C. Guth, K. C. C. Soares, L. Nishimura, D. F. De Almeida, and L. C. S. Ferreira, "Random amplification of polymorphic DNA reveals serotype-specific clonal clusters among enterotoxigenic Escherichia coli strains isolated from humans," Journal of Clinical Microbiology, vol. 35, no. 6, pp. 1521-1525, 1997.

[24] G. Muyzer, E. C. De Waal, and A. G. Uitterlinden, "Profiling of complex microbial populations by denaturing gradient gel electrophoresis analysis of polymerase chain reaction-amplified genes coding for $16 \mathrm{~S}$ rRNA," Applied and Environmental Microbiology, vol. 59, no. 3, pp. 695-700, 1993.

[25] R. A. I. Abou-Shanab, P. van Berkum, and J. S. Angle, "Heavy metal resistance and genotypic analysis of metal resistance genes in gram-positive and gram-negative bacteria present in Ni-rich serpentine soil and in the rhizosphere of Alyssum murale," Chemosphere, vol. 68, no. 2, pp. 360-367, 2007.

[26] A. Hassen, N. Saidi, M. Cherif, and A. Boudabous, "Resistance of environmental bacteria to heavy metals," Bioresource Technology, vol. 64, no. 1, pp. 7-15, 1998.

[27] M. Narita, K. Chiba, H. Nishizawa et al., "Diversity of mercury resistance determinants among Bacillus strains isolated from sediment of Minamata Bay," FEMS Microbiology Letters, vol. 223, no. 1, pp. 73-82, 2003.

[28] M. Zeyaullah, B. Islam, and A. Ali, "Isolation, identification and PCR amplification of merA gene from highly mercury polluted Yamuna river," African Journal of Biotechnology, vol. 9, no. 24, pp. 3510-3514, 2010.

[29] A. O. Summers, "Organization, expression, and evolution of genes for mercury resistance," Annual Review of Microbiology, vol. 40, pp. 607-634, 1986.

[30] F. Matyar, T. Akkan, Y. Uçak, and B. Eraslan, "Aeromonas and Pseudomonas: antibiotic and heavy metal resistance species from Iskenderun Bay, Turkey (northeast Mediterranean Sea)," Environmental Monitoring and Assessment, vol. 167, no. 1-4, pp. 309-320, 2010.
[31] M. C. Hart, G. N. Elliott, A. M. Osborn, D. A. Ritchie, and P. Strike, "Diversity amongst Bacillus merA genes amplified from mercury resistant isolates and directly from mercury polluted soil," FEMS Microbiology Ecology, vol. 27, no. 1, pp. 73-84, 1998.

[32] J.-B. Ramond, T. Berthe, R. Duran, and F. Petit, "Comparative effects of mercury contamination and wastewater effluent input on Gram-negative merA gene abundance in mudflats of an anthropized estuary (Seine, France): a microcosm approach," Research in Microbiology, vol. 160, no. 1, pp. 10-18, 2009.

[33] A. M. Osborn, K. D. Bruce, P. Strike, and D. A. Ritchie, "Polymerase chain reaction-restriction fragment length polymorphism analysis shows divergence among mer determinants from gram-negative soil bacteria indistinguishable by DNADNA hybridization," Applied and Environmental Microbiology, vol. 59, no. 12, pp. 4024-4030, 1993.

[34] K. D. Bruce, "Analysis of mer gene subclasses within bacterial communities in soils and sediments resolved by fluorescentPCR-restriction fragment length polymorphism profiling," Applied and Environmental Microbiology, vol. 63, no. 12, pp. 4914-4919, 1997.

[35] V. B. Mathema, B. C. Thakuri, and M. Sillanpää, "Bacterial mer operon-mediated detoxification of mercurial compounds: a short review," Archives of Microbiology, vol. 193, no. 12, pp. 837844, 2011.

[36] A. H. Regua-Mangia, T. A. T. Gomes, M. A. M. Vieira, K. Irino, and L. M. Teixeira, "Molecular typing and virulence of enteroaggregative Escherichia coli strains isolated from children with and without diarrhoea in Rio de Janeiro city, Brazil," Journal of Medical Microbiology, vol. 58, no. 4, pp. 414-422, 2009.

[37] U. Dobrindt, "(Patho-)genomics of Escherichia coli," International Journal of Medical Microbiology, vol. 295, no. 6-7, pp. 357371, 2005.

[38] A. H. Regua-Mangia, B. C. Guth, J. R. Da Costa Andrade et al., "Genotypic and phenotypic characterization of enterotoxigenic Escherichia coli (ETEC) strains isolated in Rio de Janeiro city, Brazil," FEMS Immunology and Medical Microbiology, vol. 40, no. 2, pp. 155-162, 2004.

[39] A. H. Regua-Mangia, T. A. Tardelli Gomes, J. R. Costa Andrade et al., "Genetic analysis of Escherichia coli strains carrying enteropathogenic Escherichia coli (EPEC) markers, isolated from children in Rio de Janeiro City, Brazil," Brazilian Journal of Microbiology, vol. 34, no. 1, pp. 38-41, 2003.

[40] M. A. Schmidt, "LEEways: tales of EPEC, ATEC and EHEC," Cellular Microbiology, vol. 12, no. 11, pp. 1544-1552, 2010.

[41] S. Ishii and M. J. Sadowsky, "Escherichia coli in the environment: implications for water quality and human health," Microbes and Environments, vol. 23, no. 2, pp. 101-108, 2008.

[42] J. L. Sanz and T. Köchling, "Molecular biology techniques used in wastewater treatment: an overview," Process Biochemistry, vol. 42, no. 2, pp. 119-133, 2007. 

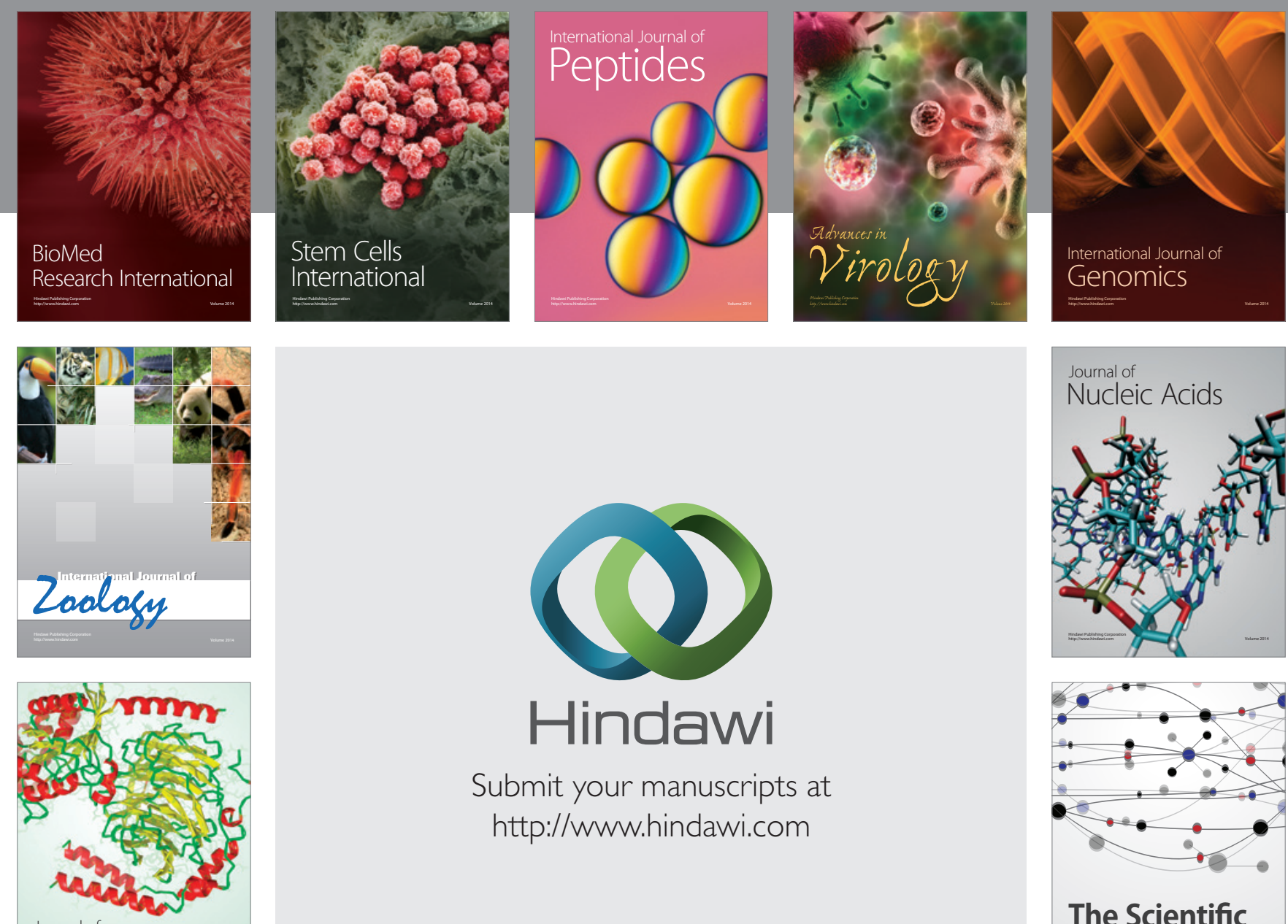

Submit your manuscripts at

http://www.hindawi.com

Journal of
Signal Transduction
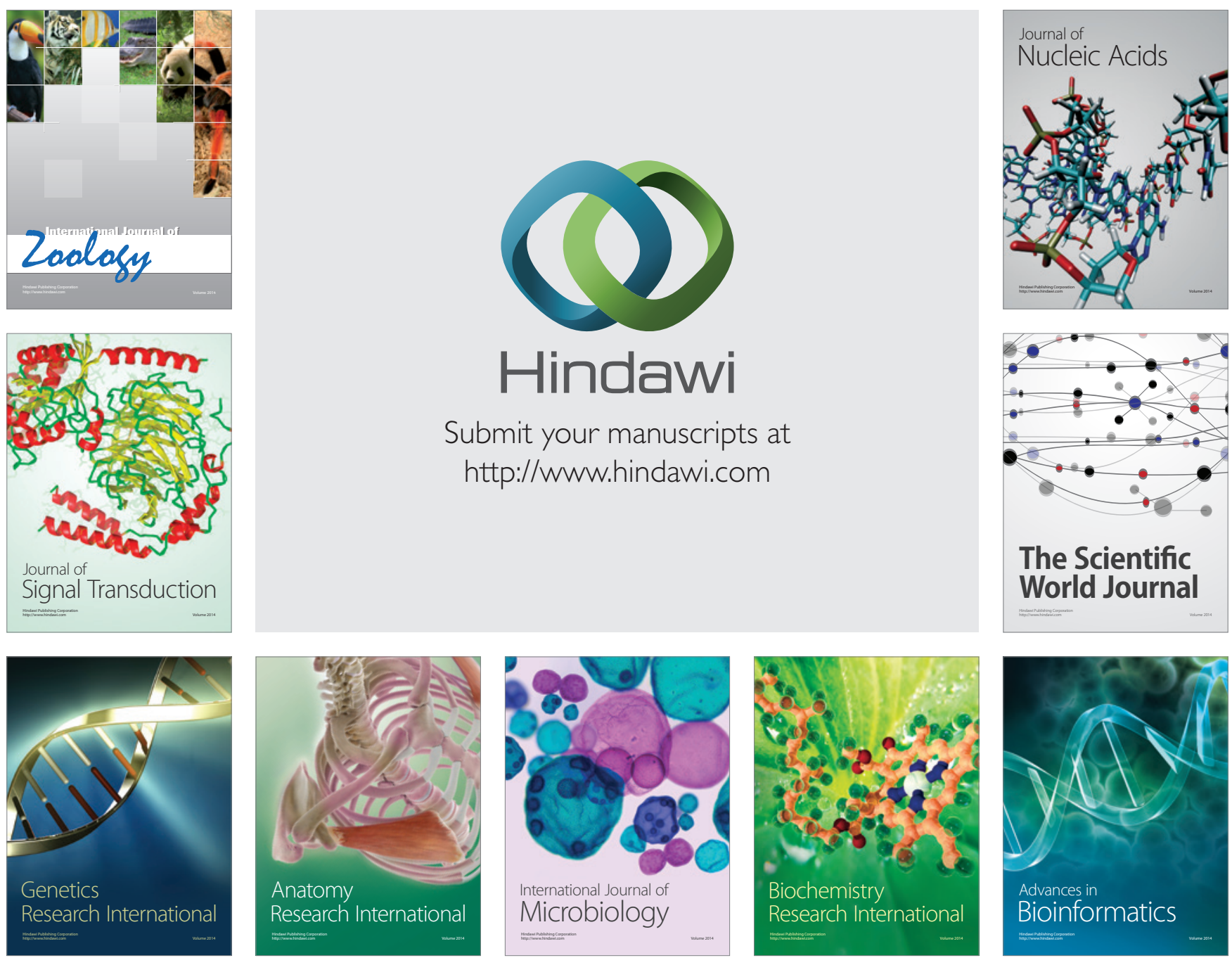

The Scientific World Journal
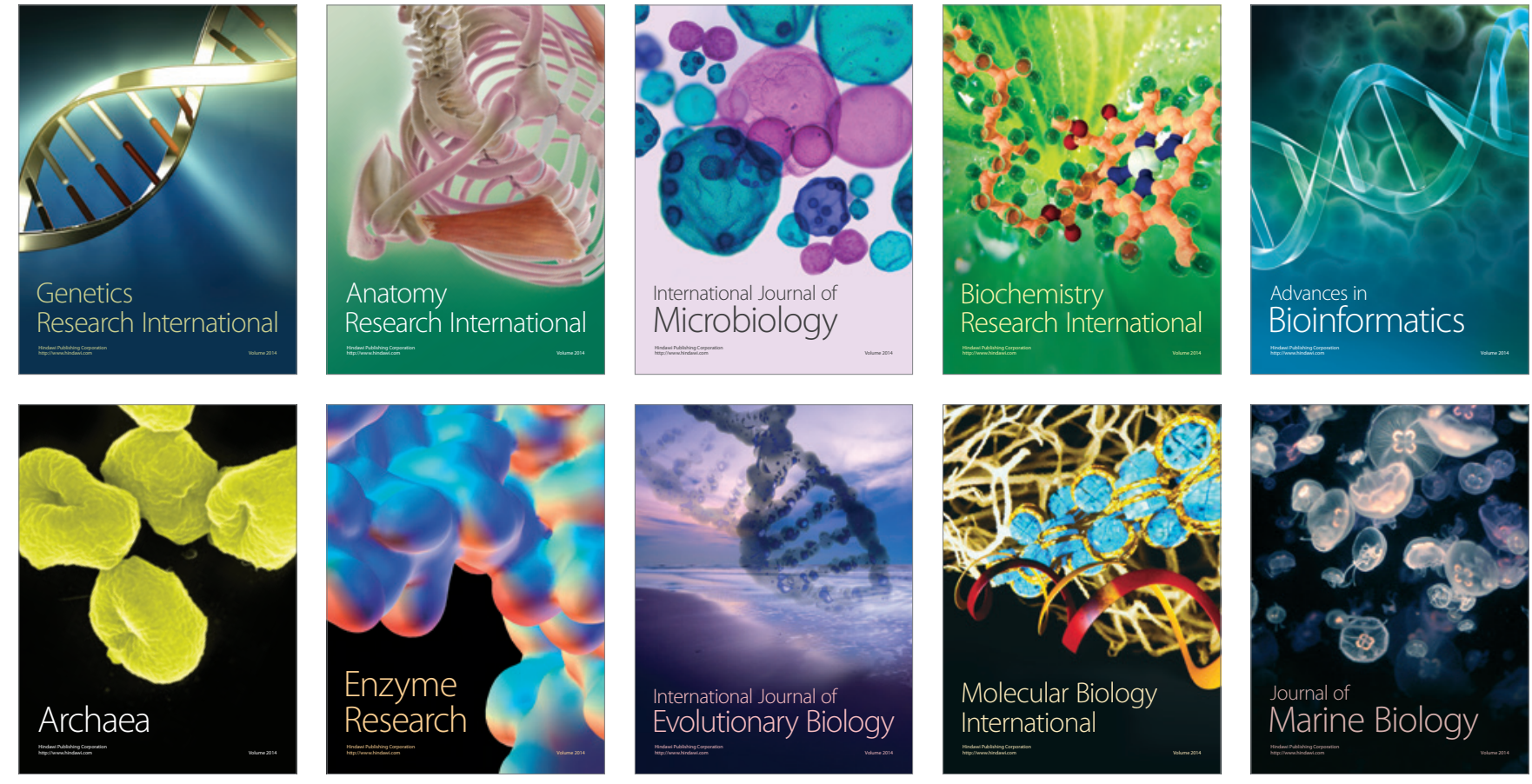